\title{
THE EFFECT OF DEPRESSIVE ILLNESS ON TIME JUDGMENT AND TIME EXPERIENCE
}

\author{
BY
}

\author{
ALEXANDER G. MEZEY* and SAMUEL I. COHEN \\ From the Institute of Psychiatry and the Maudsley Hospital, London
}

There is some experimental evidence that normal and morbid emotion differ in the nature of physiological changes associated with them (Mezey and Coppen, 1960). The following investigation was undertaken to find out whether the experience and judgment of time in morbid emotion is different from that in normal anxiety.

\section{The Experiment}

The subjects were 21 patients (12 men and nine women), suffering from an affective disorder in which depression was the dominant feature. Their ages ranged from 25 to 63 , with a mean of 44 . All were physically healthy and afebrile. They were tested shortly after their admission to the Maudsley Hospital during the period of preliminary clinical study and before active treatment was started. After recovery, or improvement sufficient for discharge from hospital, the patients were retested; 15 patients received electroconvulsive treatment, and at least 10 days separated the retest from the last treatment. The interval between the two tests varied from four to nine weeks.

The testing procedure was identical with that used in a previous experiment and described in detail on page 266 asking the patient to count at intervals of a second and his estimate of 30 seconds was measured. For time reproduction he listened to a sequence of pips at threesecond intervals and was then asked to tap at the same rate; the time taken to tap out 10 intervals was measured. He was asked to estimate the duration of the three-second interval between pips, and the total duration of the experiment, usually about 20 minutes. His assessment of his emotional state and his subjective experience of the

*Assisted by a grant from the Ford Foundation. passage of time were also recorded. In addition, the patients completed the Maudsley personality inventory; the relationship between time judgments and the personality factors measured by this questionnaire will be reported elsewhere.

\section{Results}

The results for time production by counting are shown in Table I. When depressed, the mean time taken to 'produce' 30 seconds was almost 40 seconds; however, the apparent improvement in time judgment with recovery was not statistically significant. Standard deviations and the range of results were slightly larger in the depressed state.

Table I shows the results for time reproduction by tapping. As in the previous test, the mean results obtained on recovery from depression were closer to the 30 seconds' actual duration; the difference between the results on the two occasions was not significant. Standard deviations and the range of results were also larger during depression.

Table II shows that the mean verbal estimation of the three-second interval was very accurate during depression and a full second longer on recovery, but the difference between the two was not significant. The standard deviations and the range of results were very similar on both occasions.

Table III shows the estimated total time of the experiment expressed as a percentage of the actual time, which varied from 12 to 30 minutes. The difference between the means is not significant. The standard deviations were larger and the range of results considerably wider in the depressed state.

TABle I

COUNTING AND TAPPING

\begin{tabular}{|c|c|c|c|c|c|c|c|c|}
\hline & \multicolumn{2}{|c|}{ Depressed } & \multicolumn{2}{|c|}{ Recovered } & \multicolumn{2}{|c|}{ Depressed } & \multicolumn{2}{|c|}{ Recovered } \\
\hline & 1 & 2 & 1 & 2 & 1 & 2 & 1 & 2 \\
\hline \multirow{2}{*}{$\begin{array}{l}\text { Mean (seconds) } \\
\text { S.D. } \\
\text { Range } \\
\mathbf{r}_{1,2}\end{array}$} & $\begin{array}{c}40 \cdot 3 \\
19 \cdot 3 \\
18 \cdot 8-97 \cdot 4\end{array}$ & $\begin{array}{c}37 \cdot 7 \\
18 \cdot 7 \\
16 \cdot 4-77 \cdot 0\end{array}$ & $\begin{array}{c}35 \cdot 6 \\
12 \cdot 8 \\
18 \cdot 0-68 \cdot 2\end{array}$ & $\begin{array}{c}34 \cdot 4 \\
13 \cdot 4 \\
15 \cdot 3-70 \cdot 0\end{array}$ & $\begin{array}{c}25 \cdot 7 \\
9 \cdot 0 \\
13 \cdot 8-51 \cdot 4\end{array}$ & $\begin{array}{c}25 \cdot 7 \\
5 \cdot 3 \\
17 \cdot 0-35 \cdot 6\end{array}$ & $\begin{array}{c}29 \cdot 4 \\
6 \cdot 1 \\
20 \cdot 0-45 \cdot 0\end{array}$ & $\begin{array}{c}29 \cdot 2 \\
4 \cdot 2 \\
21 \cdot 0-37 \cdot 0\end{array}$ \\
\hline & \multicolumn{2}{|c|}{+0.92} & \multicolumn{2}{|c|}{+0.98} & \multicolumn{2}{|c|}{+0.87} & \multicolumn{2}{|c|}{+0.65} \\
\hline
\end{tabular}


TABLE II

INTERVAL ESTIMATION

\begin{tabular}{l|c|c}
\hline & Depressed & Recovered \\
\hline Mean (seconds) & $3 \cdot 2$ & $4 \cdot 2$ \\
S.D. & $2 \cdot 1$ & $2 \cdot 8$ \\
Range & $0 \cdot 5-9$ & $1-10$ \\
\hline
\end{tabular}

TABLE III

TOTAL DURATION

\begin{tabular}{l|c|c}
\hline & Depressed & Recovered \\
\hline Mean (\% of actual & 90 & \\
time) & 95 \\
R.D. & $17-154$ & 25 \\
Range & & $30-110$ \\
\hline
\end{tabular}

When depressed, 16 patients reported a slowing, and some even an apparent arrest of the passage of time, describing this experience in evocative terms ('Every hour seems a year to me'; 'It is terribly slow -interminable'; 'Time? It is standing still'.) Three patients felt that time was passing normally and only two that it was passing faster than usual. On recovery from depression 15 patients reported a normal, two a slower, and four a faster subjective experience of the passage of time (Table IV). This high incidence of slowing down of the experience of time in the depressed state was statistically highly significant.

TABLE IV

SUBJECTIVE EXPERIENCE OF TIME

\begin{tabular}{l|c|c}
\hline & Depressed & Recovered \\
\hline Normal & 3 & 15 \\
Slow & 16 & 2 \\
Fast & 2 & 4 \\
\hline
\end{tabular}

\section{Discussion}

Distortion of time sense is a not uncommon symptom in psychiatric illness, particularly in affective disorders. Relatively few papers have been devoted to a clinical description of it (Straus, 1928; von Gebsattel, 1928; Lewis, 1932). Others have commented on its relevance to the existential experience of the patient, or on its psychopathological implications (Minkowski, 1929; Binswanger, 1933; Schilder, 1936; Straus, 1947; Tamarin, 1960) and three authcrs (Bouchard, 1926; Giehm, 1931;
Lewis, 1932) have approached the phenomenon experimentally.

In so far as one can generalize from our sma numbers, about three-quarters of patients sufferiro from depressive illness feel that time is passing mofe slowly than normal and this feeling tends to disappear on recovery. It is probably a particular aspect of retardation (Lewis, 1932). In normal anxiety the direction of the altered experience of time is variable slow or fast (Cohen and Mezey, 1961), and may related to depersonalization. Normal anxiety an morbid depression thus have different effects of subjective time experience.

In objective tests time production and time reproduction tended to be more accurate after recovery. In these tests, and also in the estimation of the total time of the experiment, there was a tendences to a narrower range of results and less individuar variability once the depression had lifted. However the difference between the results on the two occaro sions never reached significance level. Our inabilik? to detect an alteration of time judgment in depressio is in agreement with earlier work (Bouchard, 192 Lewis, 1932).

The effect of depression on the time experiefect and time judgment of 21 psychiatric patients investigated. The tests included production, rero duction, and verbal estimation of time inter品 ranging from one second to 30 minutes, and supplemented by introspective statements about times experience. Our findings were that depression associated with a slowing down of the experience. $\overrightarrow{o f}_{\mathrm{f}}$ time. Time judgment is not significantly impaire重数 depression.

We wish to thank our colleagues for acting as subject in the first experiment and Dr. R. H. Cawley for hî advice on statistical aspects.

\section{REFERENCES}

Binswanger, L. (1933). Uber Ideenfucht, Orell Füssli, Zürich. Bouchard, R. (1926). Sur l'évaluation du temps dans certains trouble

mentaux. Vigot Frères, Paris.
Cohen, S. I., and Mezey, A. G. (1961). J. Neurol. Neurosurg. Psychia 24, 266.

Gebsattel, E. V. von (1928). Nervenarzt, 1, 275

Giehm, G. (1931). Arch. Psychiat. Nervenkr., 95, 330

Lewis, A. (1932). Proc. roy. Soc. Med., 25, 611.

Mezey, A. G., and Coppen, A. J. (1960). J. psychosom. Res., 5, 60

Minkowski, E. (1929). Evolut psychiat., 2, 65.

Schilder, P. (1936). J. nerv. ment. Dis., 83, 530.

Straus, E. (1928). Mschr. Psychiatr. Neurol., 68, 640.

(1947). Sth. med. J. (Bgham., Ala.), 40, 254

Tamarin, G. (1960). Acta psychother. (Basel), 8, 53. 